\title{
DA RESPONSABILIDADE CIVIL E O DIREITO AMBIENTAL
}

Rachel Lopes Queiroz Chacur

Docente da Universidade do Oeste Paulista - UNOESTE.

\section{RESUMO}

Toda e qualquer ação humana resulta em um impacto no meio ambiente, o qual deve ser minimizado na equação do custo e benefício para a sociedade sempre em favor do desenvolvimento sustentável do meio ambiente. O grande desafio da sociedade contemporânea é estabelecer ações humanas que levem ao desenvolvimento técnico, econômico e social, sem maiores comprometimentos relevantes para com o equilíbrio do ecossistema. Vale ressaltar que, o apelo a sustentabilidade versus danos ambientais, não se trata de uma obrigação condicionada ao caráter filantrópico e econômico de um eixo comercial e de marketing, mas tão somente a um dever-ser de qualquer setor, organismos ou facção social. (Savitz e Weber, 2007, p.28 e p.65).O presente trabalho abordará as concepções básicas e a aplicabilidade das legislações, sanções e seus julgados.

\section{REVISÃO DE LITERATURA}

O conceito de Dano ambiental é vago, uma vez que toda e qualquer ação humana, inclusive aquelas de natureza antrópica, ensejam em alterações ambientais. Elas não devem ser consideradas um dano, pois são eticamente válidas quando inerentes as condições físicas e naturais. Outras vezes tem-se danos considerados ajustáveis a equação custo-benefícios, dos quais propiciam a subsistência e a melhoria de qualidade de vida para toda a sociedade.

Não se pode cogitar a possibilidade de dano inexistente na ordem sistêmica do meio ambiente.

Os estudiosos apresentam uma graduação de impacto ambiental e seus danos, assim classificados: em impacto de magnitude irrelevante ou impacto inevitável e necessário. 0 primeiro é por ordem natural e sistêmica do meio ambiente, enquanto que o segundo deve ser acompanhado por um estudo técnico sobre o aspecto negativo do mesmo e a viabilidade de possível compensação ou reparabilidade à degradação ambiental.

É de notar-se que a participação democrática da sociedade nas tomadas de decisões e fiscalização dos estudos de impacto ambiental determinam um avanço na forma de controle do equilíbrio do meio ambiente e possibilita o desenvolvimento sustentável. 
Neste contexto, o objetivo é dar prioridade a prevenção para a preservação ambiental ou a própria repressão, com a necessária reparação ou condenação dos agentes responsáveis pelo dano.

Há várias formas de composição do dano ambiental, seja ela pela recuperação do meio ambiente ou pela percepção da indenização derivada do ato ilícito civil ou criminal.

Nesta seara, surge atrelado ao conceito de dano ambiental, na via reflexiva, indireta e subsidiária, a responsabilidade civil do causador do dano ambiental.

O ordenamento jurídico pátrio estabelece os responsáveis e as formas de reparabilidade do dano ambiental, bem como as suas sanções.

Das relações de responsabilidade se chega à personalidade, pois não há como se conceber a sanção ou a indenização sem o individuo que as deva receber (BARRACHO, 2000, p-296).

A Constituição Federal de 1988, em seu artigo 225, § 2으, determina que: "aquele que explorar recursos minerais fica obrigado a recuperar o meio ambiente degradado, de acordo com a solução técnica exigida pelo órgão público competente, na forma da lei." O $\S 3^{\circ}$ acrescenta: "as condutas e atividades consideradas lesivas ao meio ambiente sujeitarão os infratores, pessoas físicas ou jurídicas, a sanções penais e administrativas, independentemente da obrigação de reparar o dano."

Segundo Paulo Bessa Antunes, as sanções determinam um caráter punitivo e educativo, em que determina a reparação do dano, em busca da recomposição do prejuízo causado ao meio ambiente e as vitimas, e, principalmente a prevenção de casos semelhantes que possam a vir pela repetição causar novos danos ambientais.

Para Francisco José Marques Sampaio objetiva-se a reparação ao prejuízo causado a natureza e também a coletividade, da qual é privada de um meio ambiente equilibrado, dos seus recursos naturais e de qualidade de vida.

Há reparação do dano ambiental por meio de recuperação natural ou pela via da compensação pecuniária, inclusive com a possibilidade da obtenção de lucros cessantes.

A teoria adotada é a Teoria do Risco Integral, estabelecida também no artigo 14, § 1으, Lei 6938/81, o qual reitera pela responsabilidade civil objetiva - do poluidor, obrigado, independentemente da existência de culpa, a indenizar ou reparar os danos causados ao meio ambiente e a terceiros, afetados por sua atividade (DIAS, 1954, p- 52). 
A responsabilidade civil do causador do dano ambiental, em síntese, se enquadra na responsabilidade objetiva derivada de uma ação positiva ou negativa, com resultado lesivo e nexo de causalidade meramente etiológico para manter o elo do agente ao dano, independente de culpa; a possibilidade de lesão a terceiros; o afastamento da licitude da conduta como pressuposto de excludente da responsabilidade do causador do dano; a precípua responsabilidade do Poder Público em todas as matérias que envolvam o meio ambiente; a solidariedade passiva de todos os causadores, por ação ou omissão, pelo dano ambiental, independente da existência de ação regressiva com o intuito de excludente de ilicitude, bem como de responsabilidade do agente.

No entanto, o meio de prova do dano ambiental deve ser real e determinante, pois dá ao julgador parâmetros adequados para indenizar o valor equivalente ao prejuízo causado a um bem jurídico maior. Entretanto, repele qualquer medida preventiva do Poder Judiciário, em casos excepcionais e por disposição de lei, ensejam em tutelas específicas e protetivas pleiteadas pelo Parquet.

Outra medida alternativa para a prevenção e punição efetiva do causador-poluidor trouxe o fundamento do artigo 4 o da Lei 9.605/98, o qual prevê o instituto da desconsideração da personalidade jurídica, como forma de penetração na justa composição dos danos causados por ela e a adequada responsabilidade dos causadores do dano.

Não sem olvidar, o Poder Público tem o papel principal de preservar o meio ambiente e por meio do poder de policia, fiscalizar a conduta comissiva ou omissiva dos sujeitos, com a imposição das devidas infrações administrativas ou judiciais.

São os princípios que norteiam a atuação do Poder Público: o princípio da legalidade; b) princípio da anterioridade; $\quad$ c) princípio da tipicidade; d) princípio da exigência da voluntariedade.

Para tanto, direcionado o contexto pelos princípios norteadores do Poder Público, para cada qual ação ou omissão, haverá um tipo administrativo que a qualificará como uma infração administrativa ambiental e suas respectivas sanções administrativas e judiciais.

Dentre as sanções aplicáveis serão considerados os princípios da proporcionalidade, o principio do devido processo legal (artigo 5, inciso LIV da Constituição Federal de 1988) e o princípio da motivação das decisões judiciais. Sendo classificadas em penalidades de advertência, prazos para regularização sob pena cominatória, multa simples ou multa diária. Assim como outras ordens administrativas de embargo de obra, demolição, remoção de ato ilícito, destruição ou 
inutilização de produtos, busca e apreensão, suspensão parcial ou total de atividades, restrição de direito, entre outros. Como forma regulatória e fiscalizatória da conduta ou atividades nocivas e degradáveis ao meio ambiente (Lei 9605/98).

Esses procedimentos administrativos amparados pelos princípios máximos da ampla defesa e do contraditório.

No entanto, nos planos fáticos verifica-se o esvaziamento do poder de polícia do órgão administrativo, principalmente dos agentes fiscalizadores, e, por conseguinte, a litigância habitual dos agentes-poluidores, na certeza da impunibilidade até pela via judicial.

Mesmo com adotada Teoria do Risco Integral ${ }^{1}$ no âmbito da responsabilidade civil para matéria versada de meio ambiente e a tipificação de Crimes Ambientais causados pela Pessoa Física ou Jurídica (Artigo 225, § 3으 CF), ora são os agentes beneficiados, pois a acepção da lei não os considera criminosos ao cometerem atos ilícitos contra o Meio Ambiente.

Geralmente, o entendimento da jurisprudência, coleciona a possibilidade de transação penal, suspensão condicional do processo ou suspensão da pena, para a responsabilidade criminal de pessoa física. Em contrapartida, o entendimento do Superior Tribunal de Justiça (STJ), admite a necessidade uma maior ênfase na responsabilidade desses infratores e aceitam a penalização, inclusive, da responsabilidade da pessoa jurídica, desde que comprovada a origem da delegação ou ordem para a execução do ato pelo seu representante legal e haja tão somente em beneficio econômico para a sua empresa.

\section{CONCLUSÃO}

Apesar do sistema constitucional e processual prever mecanismos garantísticos de tutela do meio ambiente, verifica-se ainda que, o cumprimento da lei e seus regramentos, bem como de suas sanções são postergadas para findar no cotejo de uma irreversão do dano ambiental.

\section{REFERÊNCIAS}

BARRACHO, J. A. O. Responsabilidade Civil por Dano ao Meio Ambiente. Editora Del Rey, Belo Horizonte, 2000.

DIAS, José de Aguiar. Da Responsabilide Civil. Rio de Janeiro, Forense, v. I, 1954, p-52).

\footnotetext{
${ }^{1}$ Alguns autores acrescentam que a responsabilidade objetiva por dano ambiental também decorre da teoria do risco-proveito ou "risco do usuário": quem obtém lucros com determinada atividade deve arcar também com os prejuízos causados à natureza, evitando assim "a privatização dos lucros e socialização dos prejuízos" (KRELL, Andreas Joachim. Concretização do dano ambiental. Objeções à teoria do "risco integral". (http://jus.com.br/revista/doutrina/texto.asp?id=1720) Acesso em 07 abr. 2002. p. 3)
} 
FENKER, E. A.(a) Análise custo-benefício aplicável ao meio-ambiente. Disponível em:<http://www.ambientebrasil.com.br/noticias/index.php3?action=ler\&id=24988>. Acesso em:02/09/2007.

KRELL, Andreas Joachim. Concretização do dano ambiental. Objeções à teoria do "risco integral". (http://jus.com.br/revista/doutrina/texto.asp?id=1720) Acesso em 07 abr. 2002. p. 3.

MILARÉ, Édis. Direito do Ambiente. Doutrina - prática - jurisprudência - glossário. 2. ed. rev., ampl. e atualiz. São Paulo: RT, 2001. p. 427 e 428.

MILARÉ, ÉDIS. Direito do ambiente: doutrina - jurisprudência - glossário. São Paulo: Ed. RT, 2005.

ROCHA, Julio Cesar de Sá da Rocha. Direito Ambiental e Meio Ambiente do Trabalho. Dano, Prevenção e Proteção Jurídica. Editora LTr, 1997. 